DOI 10.18551/rjoas.2021-11.11

\title{
ANALYSIS OF FACTORS AFFECTING ECONOMIC GROWTH AND SOCIAL DEVELOPMENT OF ROAD AND PORT DEVELOPMENT
}

\author{
Astuti Suprapti Tri ${ }^{*}$ \\ Postgraduate Program of Management of Natural Resources and the Environment, \\ University of Lambung Mangkurat, Banjarbaru, Indonesia \\ Mahyudin Idiannor \\ Faculty of Fisheries and Marine Affairs, University of Lambung Mangkurat Banjarbaru, \\ Indonesia \\ Bachri Ahmad Alim \\ Faculty of Economics, University of Lambung Mangkurat Banjarbaru, Indonesia
}

\section{Mahmud}

Program Study of Civil Engineering, University of Lambung Mangkurat Banjarbaru, Indonesia

*E-mail: astuti@gmail.com

\begin{abstract}
Infrastructure development is one of the important, vital and strategic things to accelerate the development process, both nationally, regionally to the regional or village level. In principle, the development of road and port infrastructure has a strategic role in economic growth and regional development, including coastal communities in South Kelumpang District. The purpose of this study is to analyze the factors that influence the economic growth and social development of the construction of roads and ports. This research was conducted with a quantitative approach, with the type of research used was correlation/associative research. The research was conducted from February to April 2021 in South Kelumpang District, Kotabaru Regency, South Kalimantan. The types of data used in this study are primary and secondary data. Primary data were obtained from respondents through interviews and observations related to the construction of roads and ports in South Kelumpang District. Respondents in the study were the people of South Kelumpang District as many as 149 respondents. Data collection methods used in this study include; a) literature study (desk study), b) survey (interview) and c) field observation. The data analysis method used in this research is SEM analysis. The results showed that there are a number of factors that influence economic growth, namely 1 ) road construction $(2,048), 2)$ port development $(2,571)$ and 3$)$ regional development $(2,307)$. Meanwhile, social development is influenced by 2 factors, namely 1 ) road construction $(4,859)$ and 2$)$ port development $(2,285)$. In addition, the results of the influence test on regional development factors are also obtained which are influenced by 1) road construction (3.270) and 2) port development (4.104). Meanwhile, community welfare factors are influenced by 1) direct economic growth (4.426), and 2) regional development (4.681).
\end{abstract}

\section{KEY WORDS}

Factor, growth, economy, road, port.

Development is defined as an effort to advance and change an area in a planned manner. According to Siagian (2001) development is an effort of growth and change that is planned and carried out consciously by a nation, state and government towards modernity in the context of developing the nation. On the other hand, development is also an indicator of change for a region, including a nation (Arsyad, 1999). Likewise, the development of road and port infrastructure, which is intended to provide changes to people's lives in an area (David, 1999). 
Infrastructure development is one of the important, vital and strategic things to accelerate the development process, both nationally, regionally to the regional or village level (Boediono, 2002). Infrastructure development also plays an important role as one of the driving wheels of economic growth in a region or nation, where the rate of economic growth of a region or nation cannot be separated from the availability of infrastructure such as; roads, ports and telecommunications. This is the basis so that infrastructure development becomes the foundation of sustainable economic development. According to Pranessy \& Nurazi (2012) that the increase in infrastructure and its improvement by the government is expected to spur economic growth. In principle, the development of road and port infrastructure has a strategic role in economic growth and regional development, including coastal communities in South Kelumpang District.

The development of road and port infrastructure will encourage the economic growth of the community and region in an area. Economic growth is one indicator to see the results of the development that has been carried out and is also useful for determining the direction of development in the future (Esfahani \& Ramirez, 2002). The process of a development is believed to bring about change and also have a positive impact on people's lives (Antle \& Heidebrink, 1995). For this reason, road and port builders in the South Kelumpang District are the main link for coastal communities in the area. This is because the South Kelumpang District is a coastal area in general which is bordered by the sea and the other part is an estuary or river area. This condition causes people in South Kelumpang District to rely heavily on water transportation modes (rivers and seas) which are connected to ports, in addition to land transportation modes (roads). On the other hand, the main life of the people in South Kelumpang District is oil palm farmers with land and water transportation systems. For this reason, it is important to conduct research related to the analysis of factors influencing economic growth and social development of road and port construction.

\section{METHODS OF RESEARCH}

This research was conducted with a quantitative approach, with the type of research used was correlation/associative research. The research was conducted from February to April 2021 in South Kelumpang District, Kotabaru Regency, South Kalimantan. The types of data used in this study are primary and secondary data. Primary data were obtained from respondents through interviews and observations related to the construction of roads and ports in South Kelumpang District. This is as stated by Yusuf and Daris (2018) that primary data is data obtained directly from the field/research object, both in the form of measurements, observations and interviews. While secondary data is data obtained from the results of searching related documents. This is as stated by Nasution (2011) that secondary data generally comes from searching documents in the library or reports/documents, and the results of previous researchers.

Data collection methods are techniques or ways to obtain or collect data needed in research analysis (Creswell, 2008; Ferdinand, 2016). Data collection methods used in this study include; a) literature study (desk study), b) survey (interview) and c) field observation. The literature study method is carried out by tracing theories and results of previous research related to the factors that affect economic growth and social development as a result of infrastructure development, especially roads and ports. The survey method was carried out to obtain information directly from the community, in which in this activity interviews were conducted with the community in South Kelumpang District on a number of people (respondents) using the simple random sampling method. While the observation method is carried out by direct observation of the object of research in this case is the existence of road and port construction in South Kelumpang District, and various socio-economic activities of the community as an enrichment of study material. Respondents in the study were the people of South Kelumpang District as many as 149 respondents.

The data analysis method used in this study is SEM (structural equation modeling) analysis. SEM analysis is a statistical technique used to build and test statistical models which are usually in the form of causal models (Shahrir et al., 2020; Wong, 2013). The 
advantage of the SEM method is that it can test all variables or simultaneously (simultaneously) (Sarwono \& Narimawati, 2015). It is further stated that in the SEM method there are 2 models which are the basis for developing the SEM method, namely; a) measurement model and b) structural model. The measurement model is a model that describes the relationship between indicators and constructs (latent variables). Meanwhile, the structural model is a model that describes the relationship between constructs (latent/unobserved variables or variables that are not directly measured), which generally consist of independent and dependent variables (Syarir et al., 2020). In this study the model developed is described as follows:

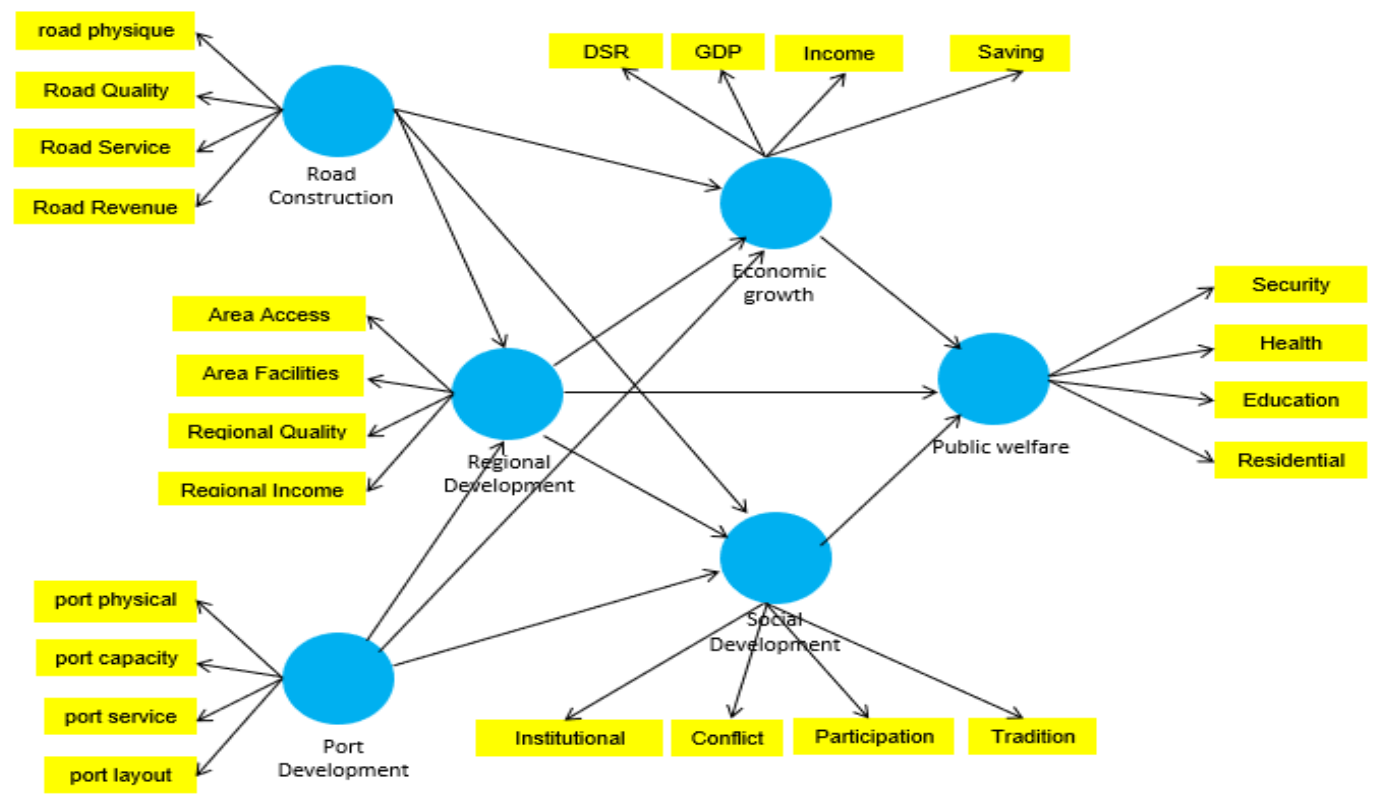

Figure 1 - SEM analysis structure model

The model is intended to test the hypotheses that have been built. The research hypothesis is an initial conclusion or a temporary answer to a problem that is still presumption because it still has to be proven true (Vardiansyah, 2008). It is further stated that the hypothesis tries to provide a temporary answer to the problem to be studied. The hypotheses were built based on theories and concepts related to the research being studied. The details of the hypothesis built in this study are as follows:

Table 1 - Research Hypothesis

\begin{tabular}{|l|l|}
\hline Hypothesis & Description \\
\hline $\mathrm{H} 1$ & There is an effect of road construction on economic growth \\
\hline $\mathrm{H} 2$ & There is an influence of road construction on social development \\
\hline $\mathrm{H} 3$ & There is an influence of road construction on regional development \\
\hline $\mathrm{H} 4$ & There is an effect of port development on economic growth \\
\hline $\mathrm{H} 5$ & There is an influence of port development on social development \\
\hline $\mathrm{H} 6$ & There is an influence of port development on regional development \\
\hline $\mathrm{H} 7$ & There is an influence of regional development on economic growth \\
\hline $\mathrm{H} 8$ & There is an influence of road construction on social development \\
\hline $\mathrm{H} 9$ & The relationship/influence of regional development on the welfare of the community \\
\hline $\mathrm{H} 10$ & The relationship/influence of economic growth on people's welfare \\
\hline $\mathrm{H} 11$ & The relationship/influence of social development on the welfare of society \\
\hline
\end{tabular}

SEM analysis in this study was carried out using the SEM-PLS approach or variantbased SEM with the help of SmartPLS software. SEM-PLS (Structural Equation ModelingPartial Least Squares) was used to test the model in this study, providing a systematic evaluation of the results of SEM-PLS as suggested by Hair et al. (2017). This study used the 
SEM-PLS method, more specifically, SmartPLS 3 (Ringle et al., 2015) to assess structural models and measurements. Evaluation of the model in Lisrel can be done by 1) Evaluation of the Measurement Model (Outer Model) and 2) Evaluation of the Structural Model (Inner Model).

\section{RESULTS AND DISCUSSION}

T-test or T-Statistic is a value to describe the significance of the model. T-Statistic evaluation was carried out with a 95\% confidence level (sign. 0.05) using a two-tailed (twotailed) method. The t-test assessment indicator (t-statistics) is that the value must be above > 1.960 then it is declared significant or by looking at the $p$-Value value it must be less than alpha $<0.05$. The following are the results of the boostraping analysis.

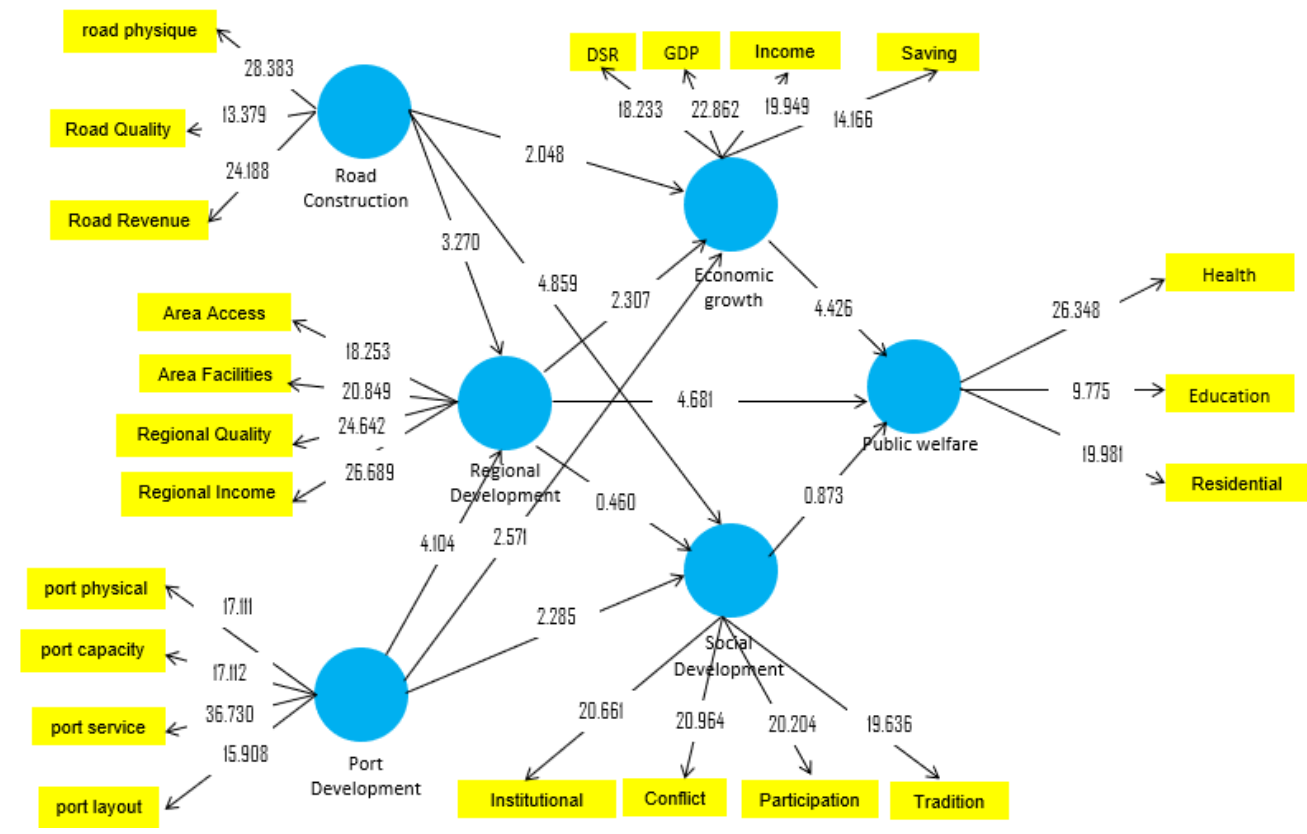

Figure 2 - Model structure (Bootstrapping)

Table 2 - T-Statistic Value

\begin{tabular}{|l|l|l|l|l|l|}
\hline $\mathrm{n} / \mathrm{n}$ & $\begin{array}{l}\text { Original } \\
\text { Sample (O) }\end{array}$ & $\begin{array}{l}\text { Sample } \\
\text { Mean (M) }\end{array}$ & $\begin{array}{l}\text { Standard } \\
\text { Deviation (STDEV) }\end{array}$ & $\begin{array}{l}\text { T Statistics } \\
(|\mathrm{O} / \mathrm{STDEV}|)\end{array}$ & $\begin{array}{l}\text { P- } \\
\text { Values }\end{array}$ \\
\hline $\begin{array}{l}\text { Road Construction -> } \\
\text { Socio-Cultural Development }\end{array}$ & 0.626 & 0.603 & 0.129 & 4.859 & 0.000 \\
\hline $\begin{array}{l}\text { Road Construction -> } \\
\text { Regional Development }\end{array}$ & 0.420 & 0.421 & 0.128 & 3.270 & 0.001 \\
\hline $\begin{array}{l}\text { Road Construction -> } \\
\text { Economic growth }\end{array}$ & 0.280 & 0.268 & 0.137 & 2.048 & 0.041 \\
\hline $\begin{array}{l}\text { Port Development -> } \\
\text { Socio-Cultural Development }\end{array}$ & 0.189 & 0.184 & 0.083 & 2.285 & 0.023 \\
\hline $\begin{array}{l}\text { Port Development -> } \\
\text { Regional Development }\end{array}$ & 0.347 & 0.349 & 0.085 & 4.104 & 0.000 \\
\hline $\begin{array}{l}\text { Port Development -> } \\
\text { Economic growth }\end{array}$ & 0.273 & 0.275 & 0.106 & 2.571 & 0.011 \\
\hline $\begin{array}{l}\text { Socio-Cultural Development }-> \\
\text { Public welfare }\end{array}$ & 0.108 & 0.119 & 0.123 & 0.873 & 0.383 \\
\hline $\begin{array}{l}\text { Regional Development -> } \\
\text { Public welfare }\end{array}$ & 0.399 & 0.384 & 0.085 & 4.681 & 0.000 \\
\hline $\begin{array}{l}\text { Regional Development }> \\
\text { Socio-Cultural Development }\end{array}$ & 0.060 & 0.081 & 0.131 & 0.460 & 0.646 \\
\hline $\begin{array}{l}\text { Regional Development }> \\
\text { Economic growth }\end{array}$ & 0.276 & 0.293 & 0.120 & 2.307 & 0.022 \\
\hline $\begin{array}{l}\text { Economic Growth -> } \\
\text { Public welfare }\end{array}$ & 0.401 & 0.408 & 0.091 & 4.426 & 0.000 \\
\hline
\end{tabular}


Based on the results of the boostraping statistical test or t-test, the relationship between the latent variables was obtained. T-test is a value to describe the significance of the model. The t-test or T-Statistics was carried out with a 95\% confidence level (sign. 0.05) using a two-tailed (two-tailed) method. The t-test assessment indicator (t-statistics) is that the value must be above $>1.960$ so that it can be declared significant (real) or by looking at the $\mathrm{p}$-value, which value must be less than alpha $<0.05$. The following are the results of the t-test (t-statistics) analysis.

The results of the analysis show that there are 2 (two) variables that do not show significance, namely; the variable of Socio-Cultural Development on Community Welfare, and the variable of Regional Development of Socio-Cultural Development. The two variables have a T-Statistic (T-Calculate) value smaller than 1.960 and a P-Value value greater than > 0.05 .

Fit model is a value that shows how well the resulting model is. Fit model describes how well / fits the model obtained from a series of measurements made. According to (Mourad \& Valette-Florence, 2016) that SmartPLS provides bootstrap-based inferential statistics from SRMR criteria. Furthermore, according to Henseler (2010) that there is a measure of model fit, namely the d_ULS criteria (squared Euclidean distance) and d_G (geodetic distance), where the d_G criterion is built on the calculation of the PLS-SEM eigenvalues. The fit model indicator can be estimated from the NFI value. The following are the results of the analysis as follows:

Table 3 - Fit Model Fit Indicators

\begin{tabular}{|l|l|l|}
\hline $\mathrm{n} / \mathrm{n}$ & Saturated Model & Estimated Model \\
\hline SRMR & 0.092 & 0.095 \\
\hline d_ULS & 2.129 & 2.269 \\
\hline d_G & 1.213 & 1.238 \\
\hline Chi-Square & 943.767 & 957.118 \\
\hline NFI & 0.652 & 0.648 \\
\hline$R^{2}$ & 0.686 & 0.680 \\
\hline
\end{tabular}

Table 4 - Hypothesis Test

\begin{tabular}{|c|c|c|c|c|c|c|c|}
\hline Hypothesis & description & $\begin{array}{l}\text { Original } \\
\text { Sample } \\
\text { (O) }\end{array}$ & $\begin{array}{l}\text { Sample } \\
\text { Mean } \\
\text { (M) }\end{array}$ & $\begin{array}{l}\text { Standard } \\
\text { Deviation } \\
\text { (STDEV) }\end{array}$ & $\begin{array}{l}\text { T Statistics } \\
(|\mathrm{O} / \mathrm{STDEV}|)\end{array}$ & P-Values & $\begin{array}{l}\text { Decision } \\
\text { (influence) }\end{array}$ \\
\hline $\mathrm{H} 1$ & $\begin{array}{l}\text { Road Construction -> } \\
\text { Economic growth }\end{array}$ & 0.280 & 0.268 & 0.137 & 2.048 & 0.041 & $\begin{array}{l}\text { Significant } \\
\text { Positive }\end{array}$ \\
\hline $\mathrm{H} 2$ & $\begin{array}{l}\text { Road Construction -> } \\
\text { Socio-Cultural Development }\end{array}$ & 0.626 & 0.603 & 0.129 & 4.859 & 0.000 & $\begin{array}{l}\text { Significant } \\
\text { Positive }\end{array}$ \\
\hline H3 & $\begin{array}{l}\text { Road Construction -> } \\
\text { Regional Development }\end{array}$ & 0.420 & 0.421 & 0.128 & 3.270 & 0.001 & $\begin{array}{l}\text { Significant } \\
\text { Positive }\end{array}$ \\
\hline $\mathrm{H} 4$ & $\begin{array}{l}\text { Port Development -> } \\
\text { Economic growth }\end{array}$ & 0.273 & 0.275 & 0.106 & 2.571 & 0.011 & $\begin{array}{l}\text { Significant } \\
\text { Positive }\end{array}$ \\
\hline H5 & $\begin{array}{l}\text { Port Development -> } \\
\text { Socio-Cultural Development }\end{array}$ & 0.189 & 0.184 & 0.083 & 2.285 & 0.023 & $\begin{array}{l}\text { Significant } \\
\text { Positive }\end{array}$ \\
\hline $\mathrm{H} 6$ & $\begin{array}{l}\text { Port Development -> } \\
\text { Regional Development }\end{array}$ & 0.347 & 0.349 & 0.085 & 4.104 & 0.000 & $\begin{array}{l}\text { Significant } \\
\text { Positive }\end{array}$ \\
\hline $\mathrm{H} 7$ & $\begin{array}{l}\text { Regional Development -> } \\
\text { Economic growth }\end{array}$ & 0.276 & 0.293 & 0.120 & 2.307 & 0.022 & $\begin{array}{l}\text { Positive Not } \\
\text { Significant }\end{array}$ \\
\hline $\mathrm{H} 8$ & $\begin{array}{l}\text { Regional Development -> } \\
\text { Socio-Cultural Development }\end{array}$ & 0.060 & 0.081 & 0.131 & 0.460 & 0.646 & $\begin{array}{l}\text { Positive Not } \\
\text { Significant }\end{array}$ \\
\hline $\mathrm{H} 9$ & $\begin{array}{l}\text { Regional Development -> } \\
\text { Public welfare }\end{array}$ & 0.399 & 0.384 & 0.085 & 4.681 & 0.000 & $\begin{array}{l}\text { Significant } \\
\text { Positive }\end{array}$ \\
\hline $\mathrm{H} 10$ & $\begin{array}{l}\text { Economic Growth -> } \\
\text { Public welfare }\end{array}$ & 0.401 & 0.408 & 0.091 & 4.426 & 0.000 & $\begin{array}{l}\text { Significant } \\
\text { Positive }\end{array}$ \\
\hline $\mathrm{H} 11$ & $\begin{array}{l}\text { Socio-Cultural Development -> } \\
\text { Public welfare }\end{array}$ & 0.108 & 0.119 & 0.123 & 0.873 & 0.383 & $\begin{array}{l}\text { Positive Not } \\
\text { Significant }\end{array}$ \\
\hline
\end{tabular}

The SRMR (Standardized Root Mean Square) value shows a value smaller than $<0.1$, which is 0.09 so that the model is considered fit. This is in accordance with the statement of $\mathrm{Hu}$ \& Bentler (1999) that the SRMR value $<0.1$ has a match between the observed correlations/relationships. The same thing was also stated (Garthwaite, 1994) that values 
less than 0.10 were categorized as suitable. While the value of d_ULS (the square Euclidean distance) and the value of d_G (the geodesic distance) is the value of the distance, which indicates how far the distance between the model and the data. The Chi-Square value is the sensitivity value to the number of data or samples, where the larger the data, the higher the chi-square value. The Normal Fit Index (NFI) value ranges from 0 to 1.0, if the value is close to 1 , then the model is more suitable, and vice versa if Prasetyo's value is getting smaller or closer to zero $(0)$ then the model is not suitable. The NFI value also shows that the model is relatively acceptable, namely 0.652 or $65.20 \%$ of the resulting model has been declared fit. Thus it can be concluded that the model is quite good. According to (Lohmöller, 1988) that the closer the NFI to 1, the better the fit of the model. Based on these criteria, it can be concluded that the model is relatively fit.

The hypothesis is the formulation of the initial research statement which is relatively weak in the level of truth and must be tested using certain techniques. According to (Kerlinger, 1973) that the hypothesis is a statement of the alleged relationship between two or more variables. It is further stated that the alleged answer is a temporary truth, which will be tested for truth with data collected through research. Hypothesis testing is carried out to prove the hypothesis that was built at the beginning of the study.

The results of the analysis of hypothesis testing were obtained that there were 2 hypotheses that were not significant, namely; the influence of regional development on sociocultural development, that is, the t-test value $(0.460)$ is smaller than the t-table value $=1.960$ with a P-Value $=0.646$ greater than alpha (0.05), and the influence of socio-cultural development on welfare the community, namely the t-test value $(0.870)$ is smaller than the ttable value $=1.960$ with the $P$-Value $=0.383$ greater than alpha $(0.05)$. These results are in line with the results of Posumah's research (2015) that there is an influence of infrastructure development on investment in the Minahasa Landmark Regency. The same thing was also obtained by Panjaitan et al., (2019) that the construction of road infrastructure has a positive impact on the opportunities of the population to work and reduces income inequality in North Sumatra Province.

\section{CONCLUSION}

The results showed that there are a number of factors that influence economic growth, namely 1) road construction $(2,048), 2)$ port development $(2,571)$ and 3 ) regional development $(2,307)$. Meanwhile, social development is influenced by 2 factors, namely 1) road construction $(4,859)$ and 2 ) port development $(2,285)$. In addition, the results of the influence test on regional development factors are also obtained which are influenced by 1) road construction (3.270) and 2) port development (4.104). Meanwhile, community welfare factors are influenced by 1) direct economic growth (4.426), and 2) regional development (4.681).

\section{REFERENCES}

1. Antle, J.M. and G. Heidebrink. 1995. Environment and Development, Theory and International Evidence. Economic Development and Cultural Change, Volume 43 (3), pp.603-625.

2. Arsyad, L. 1999. Ekonomi Pembangunan. Yogyakarta: Bagian Penerbitan Sekolah Tinggi Ilmu Ekonomi YKPN.

3. Boediono. 2002. Pengantar Ekonomi, (Jakarta: Erlangga, 150 Halaman.

4. Creswell John W. 2008. Educational Researchs: Planning, Conducting, And Evaluating Quantitative and Qualitative Research, (New Jersey, Pearson Education Inc, Hal.326.

5. David, C. 1999. Infrastucture's contribution to Aggregate Output". World Bank Policy Research working paper No.2246.

6. Esfahani Hadi, and Maria Teresa Ramirez. 2002. Institutions, Infrastructur and Economic Growth. Journal of Development Economics 70, pp.443-77. 
7. Ferdinand, P. D. A. 2016. Metode Penelitian Manajemen: Pedoman Penelitian untuk Skripsi, Tesis and Disertasi Ilmu Manajemen. Undip, Semarang.

8. Garthwaite, Paul H. 1994. An Interpretatiom of Partial Least Squares. Journal of the American Statistical Association, 89(425), p.122.

9. Hair Joseph, F., Hult, G. T. M., Ringle, C. M., Sarstedt, M. 2017. A Primer on Partial Least Squares Structural Equation Modeling (PLSSEM) (2nd Edition.). Thousand Oaks, CA: Sage.

10. Kerlinger. 2006. Asas-Asas Penelitian Behavioral. Yogyakarta: Gadjah Mada University Press.

11. Nasution, S. 2011. Metode Research. Jakarta: Bumi Aksara.

12. Nazir, Moh. 2013. Metode Penelitian.Bogor: Ghalia Indonesia.

13. Nisfiannoor, Muhammad. 2009. Pendekatan Statistika Modern untuk Ilmu Sosial. Salemba Humatika. Jakarta.

14. Panjaitan, Hendra Andy Mulia., Mulatsih., Sri Rindayati., Wiwiek. 2019. Analisis Dampak Pembangunan Infrastruktur terhadap Pertumbuhan Ekonomi Inklusif Provinsi Sumatera Utara. [Disertasi] IPB University. Bogor.

15. Pranessy, Lise. Nurazi, R. 2012. Pengaruh Pembangunan Infrastruktur terhadap Pertumbuhan Ekonomi Provinsi Bengkulu. Ekonomi and Perencanaan Pembangunan, Vol. 04 No. 03.

16. Posumah, Ferdy. 2015. Pengaruh Pembangunan Infrastruktur terhadap Investasi di Kabupaten Minahasa Tengara. Jurnal Berkala Ilmiah Efisiensi, Vol.15 No.02.

17. Ringle Christian M., Marko Sarstedt., Rebecca Mitchell., Siegfried P. Gudergan. 2018. Partial least squares structural equation modeling. The International Journal of Human Resource Management 31(1):1-27.

18. Sarwono Jonathan., \& Umi Narimawati. 2015. Membuat Skripsi, Tesis, and Disertasi dengan Partial Least Square SEM (PLS-SEM). Yogyakarta: Penerbit Andi. 226 hal.

19. Siagian P Sondang. 2001. Administrasi Pembangunan, Konsep Dimensi and Strategi. Bina Aksara Jakarta.

20. Sugiyono. 2015. Metode Penelitian Bisnis. Bandung: Alfabet.

21. Syahrir., Danial., Eni Yulinda., Muhammad Yusuf. 2020. Aplikasi Metode SEM-PLS dalam Pengelolaan Sumberdaya Pesisir and Lautan. PT Penerbit IPB Press. 179p.

22. Vardiansyah, Dani. 2008. Filsafat IImu Komunikasi: Suatu Pengantar, Indeks, Jakarta. Hal.10.

23. Wong, K. K. 2013. Partial Least Squares Structural Equation Modeling (PLS-SEM) Techniques Using SmartPLS. Marketing Bulletin, (24), 1.

24. Yusuf, M., Daris, L. 2018. Analisis Data Penelitian; Teori \& Aplikasi dalam Bidang Perikanan IPB Press, Bogor. 